\title{
KAJIAN PELESTARIAN KAUMAN SEMARANG SEBAGAI KAWASAN WISATA RELIGI
}

\author{
Preservation Study of Kauman Semarang as Religious Tourism Area
}

Laila Nur Tsani ${ }^{1}$, Rina Kurniati ${ }^{2}$

Diterima: 14 September 2018

Disetujui:17 Agustus 2018

\begin{abstract}
Abstrak: Kauman yang dikenal sebagai kampung dengan nuansa religius yang tinggi semakin memudar nilai, karakter, dan budayanya seiring perkembangan jaman. Oleh karena itu tujuan dari penelitian ini adalah untuk mengkaji pelestarian Kauman Semarang sebagai kawasan wisata religi. Metode penelitian dalam penelitian ini menggunakan analisis deskriptif kualitatif dengan teknik pengumpulan data berupa wawancara dan observasi lapangan. Hasil dari penelitian ini adalah upaya pelestarian kawasan yang didukung oleh pengembangan wisata religi di Kauman. Pengembangan dilakukan terhadap sarana dan prasarana pendukung wisata serta potensi wisata yang ada di Kauman berupa wisata kuliner dan edukasi religi dari pondok pesantren.
\end{abstract}

\section{Kata kunci: pelestarian kawasan, Kauman Semarang, wisata religi}

\begin{abstract}
Kauman, which is known as a village with a high religious nuance, fades its values, character and culture as the times progress. Therefore the purpose of this study is to study the preservation of Kauman Semarang as a religious tourism area. The research method in this study uses qualitative descriptive analysis with data collection techniques in the form of interviews and observations. The results of this study are preservation that are supported by the development of religious tourism in Kauman. The development is carried out on facilities and infrastructure for tourism support and tourism potential in Kauman in the form of culinary tours and religious education from Islamic boarding schools.
\end{abstract}

Keywords: preservation, Kauman Semarang, religious tourism

\section{PENDAHULUAN}

Pelestarian menurut Undang-Undang No.11 Tahun 2010 Tentang Cagar Budaya adalah upaya dinamis untuk mempertahankan keberagaman Cagar Budaya dan nilainya dengan cara melindungi, mengembangkan, dan memanfaatkannya. Sedangkan yang dimaksud dengan kawasan bersejarah/ kawasan Cagar Budaya berdasarkan UndangUndang No.11 Tahun 2010 Tentang Cagar Budaya merupakan satuan ruang geografis yang memiliki dua Situs Cagar Budaya atau lebih yang letaknya berdekatan dan/atau memperlihatkan ciri tata ruang yang khas. Pelestarian kawasan merupakan suatu upaya menjaga, mempertahankan, dan melindungi suatu benda dan lingkunan bersejarah secara dinamis dalam hal ini upaya pelestarian dilakukan tidak hanya untuk mendapatkan tujuan pemeliharaan bangunan saja namun secara fungsional dapat menghasilkan pendapatan dan keuntungan bagi kawasan tersebut. Berdasarkan RTRW Kota Semarang Tahun 20112031 Pasal 69, Kauman merupakan salah satu kawasan cagar budaya yang harus dijaga kelestariannya. Rencana pengelolaan kawasan cagar budaya dapat dilakukan dengan cara

\footnotetext{
${ }^{1}$ Badan Perencanaan dan Penelitian dan Pengembangan Daerah Kabupaten Kebumen

2 Departemen Perencanaan Wilayah dan Kota, Fakultas Teknik, Universitas Diponegoro
} 
pelestarian pola sosial budaya masyarakat, pengaturan ukuran dan bentuk bangunan, serta pengembangan kegiatan pariwisata.

Kauman Semarang merupakan kawasan bersejarah yan memiliki pusaka budaya ragawi berupa bangunan masjid tertua di Kota Semarang yaitu Masjid Agung Semarang dan bangunan-bangunan kuno peninggalan sejarah. Kauman juga dikenal sebagai kampung dengan nuansa religius yang tinggi tercermin dari aktivitas masyarakatnya yang agamis dicerminkan oleh adanya tradisi pengajian dilaksanakan setiap hari pada majelis ta'lim yang ada di Kauman, tradisi dugderan yang merupakan kirab budaya menyambut datangnya bulan Ramadhan, serta tradisi semaan Al Qur'an yang dilaksanakan setiap bulan Ramadhan dengan jamaah dari luar kota bahkan luar Jawa. Selain itu terdapat tiga pondok pesantren besar di Kauman yang berkonsentrasi pada bidang hapalan Al Qur'an sehingga dari pondok tersebut banyak lahir para hafidz (penghapal Al Qur'an) baik dari Semarang maupun luar Semarang (Muhaimin, 2018).

Namun demikian banyak diantara bangunan peninggalan sejarah yang berubah bentuknya menjadi bangunan bergaya modern serta karakter dan budaya masyarakat Kauman yang agamis semakin memudar. Oleh karena itu dalam rangka menjaga kelestarian bangunan bersejarah serta identitas dan budaya masyarakat Kauman yang agamis dibutuhkan suatu upaya pengelolaan kawasan yang tepat. Pengelolaan kawasan yang dimaksud adalah dengan menjadikan Kauman sebagai kawasan wisata religi yang didukung oleh pencanangan Kauman sebagai Kauman Kampung Qur'an. Pada tahun 2016 para ulama bersama Walikota Semarang mencanangkan Kauman Kampung Qur'an. Hal tersebut dilatarbelakangi oleh beberapa faktor diantaranya keberadaan pondok pesantren yang fokus pada hapalan Al Qur'an, budaya masyarakat Kauman yang erat kaitannya dengan Al Qur'an seperti budaya ngaji di TPQ, mushola, dan majelis ta'lim, serta adanya percetakan Al Qur'an besar di kawasan Kauman yang mampu mencetak sampai 5000 eksemplar Al Qur'an per hari (Muhaimin, 2018).

\section{Rumusan Masalah}

Berdasarkan pada latar belakang maka diperlukan sebuah usaha untuk menjaga kelestarian Kauman agar nilai sejarah dan karakter agamis kawasan tetap terjaga. Dibutuhkan pengelolaan kawasan yang mencakup pelestarian bentuk bangunan, karakter dan budaya masyarakat, serta pengembangan kegiatan pariwisata. Salah satu tindakan yang dapat dilakukan adalah dengan manjadikan Kauman sebagai kawasan wisata religi dengan mengembangkan potensi religius yang dimiliki oleh kawasan. Upaya pelestarian yang dilakukan tidak hanya pada pada perlindungan bangunan dan tradisi peninggalan sejarah saja, akan tetapi secara fungsional dapat meningkatkan perekonomian di kawasan Kauman melalui pengembangan kegiatan wisata tersebut. Maka dari itu, peneliti menyajikan rumusan masalah penelitian ini dalam bentuk pertanyaan penelitian, yaitu bagaimana upaya pelestarian Kauman Semarang sebagai kawasan wisata religi?

\section{Pelestarian Kawasan}

Menurut Undang-Undang No.11 Tahun 2010 Tentang Cagar Budaya, pelestarian adalah upaya dinamis untuk mempertahankan keberagaman Cagar Budaya dan nilainya dengan cara melindungi, mengembangkan, dan memanfaatkannya. Konservasi dapat didefinisikan sebagai proses pemahaman, menafsirkan dan mengelola warisan arsitektur secara berurutan kepada generasi selanjutnya (Hegazy, 2015). Sedangkan kawasan bersejarah/ kawasan Cagar Budaya, berdasarkan Undang-Undang No.11 Tahun 2010 Tentang Cagar Budaya, kawasan Cagar Budaya merupakan satuan ruang geografis yang memiliki dua Situs Cagar Budaya atau lebih yang letaknya berdekatan dan/atau memperlihatkan ciri tata ruang yang khas. Dengan demikian pelestarian kawasan 
merupakan pelestarian terhadap suatu lingkungan yang terdiri dari dua atau lebih Situs Cagar Budaya secara dinamis. Maksud secara dinamis dalam hal ini adalah upaya pelestarian dilakukan tidak hanya mendapatkan tujuan pemeliharaan bangunan saja namun secara fungsional dapat menghasilkan pendapatan dan keuntungan bagi kawasan tersebut.

\section{Kriteria Pelestarian Pusaka Budaya Ragawi}

Pusaka budaya ragawi (tangible heritage) merupakan warisan yang kasat oleh mata seperti arsitektur bangunan, struktur morfologi ataupun keindahan alam (Nurini, 2011). Terdapat tolak ukur kriteria pelestarian pusaka budaya ragawi diantaranya sebagai berikut (Budiharjo, 1997: 92-93):

a. Kelangkaan, suatu jenis karya yang merupakan sisa warisan peninggalan terakhir dari gaya tertentu yang mewakili zamannya dan tidak dimiliki daerah lain.

b. Kesejarahan, lingkungan kota atau bangunan yang memiliki nilai sejarah suatu peristiwa yang mencatat peran ikatan simbolis suatu rangkaian sejarah.

c. Estetika, berkaitan dengan nilai arsitektural, meliputi bentuk, gaya konstruksi, dekorasi pemandangan, serta mewakili prestasi khusus atau gaya sejarah tertentu.

d. Superlativitas, bangunan atau bagian kota yang memiliki keistimewaan, misalnya tertua, terpanjang, terbesar, atau pertama kali sehingga memberikan kesan monumental.

e. Kejamakan, mengarah pada karya tipikal sebagai wakil dari satu kelas atau jenis khusus bangunan sekurang-kurannya 50 tahun.

f. Kualitas Pengaruh, Kehadiran suatu objek yang akan mempengeruhi kawasan di sekitarnya atau disebut dengan landmark kawasan. Landmark tersebut bermakna dan berfungsi untuk meningkatkan mutu dan citra lingkungan/kawasan di sekitarnya.

g. Nilai sosial, untuk bangunan-bangunan yang bermakna bagi masyarakat banyak.

h. Nilai komersial, sehubungan dengan peluangnya untuk dimanfaatkan bagi kegiatan ekonomis.

i. Nilai ilmiah, berkaitan dengan peranannya untuk pendidikan dan pengembangan ilmu.

\section{Kriteria Pelestarian Pusaka Budaya Ragawi}

Pusaka budaya tak ragawi (intangible heritage) merupakan peninggalan-peninggalan yang tidak kasat mata seperti seni tari, seni pertunjukan (drama atau wayang), cerita rakyat atau sejarah, dan keahlian atau keterampilan dalam menghasilkan atau membuat sesuatu, seperti seni batik, seni melukis, seni boga, dan sebagainya (Nurini, 2011). Menurut Pendidikan Pusaka Indonesia (2010:37) unsur-unsur yang mendukung kelayakan suatu pusaka budaya tak ragawi untuk dilestarikan mengacu pada Konvensi UNESCO Tahun 2003 adalah sebagai berikut:

a. Nilai pengetahuan, berkaitan dengan pemberian makna atau nilai pusaka budaya tak ragawi terhadap perkembangan ilmu pengetahuan.

b. Sumberdaya, berkaitan dengan bahan-bahan yang bersumber dari tumbuhan, hewan maupun alam yang tidak digunakan pada pusaka budaya tak ragawi yang lainnya.

c. Warisan atau keturunan, berkaitan dengan asal usul budaya tak ragawi yang diwarskan oleh suatu kaum dari enerasi ke generasi.

d. Keistimewaan, berkaitan dengan ciri khas yang melekat pada budaya tak ragawi tersebut tidak dimiliki oleh pusaka lainnya.

e. Nilai sosial budaya, berkaitan dengan nilai dan perkembangan budaya yang dianut oleh masyarakat tersebut. 


\section{Bentuk Pelestarian Pusaka Budaya Ragawi}

Berikut bentuk upaya pelestarian terhadap pusaka budaya ragawi (Antariksa, 2007:3):

a. Preservasi, tindakan atau proses penerapan langkah-langkah dalam mendukung keberadaan bentuk asli, keutuhan material bangunan/struktur, serta bentuk tanaman yang ada dalam tapak.

b. Rehabilitasi/ renovasi , upaya untuk membuat bangunan tua berfungsi kembali.

c. Konservasi, upaya untuk memelihara dan melindungi tempat-tempat yang indah dan berharga agar tidak hancur atau berubah sampai pada batas-batas yang wajar.

d. Rekonstruksi, tindakan/proses mereproduksi dengan cara membangun baru semua bentuk secara tepat sebuah bangunan yang telah hancur/hilang pada periode tertentu.

\section{Bentuk Pelestarian Pusaka Budaya Tak Ragawi}

Berikut bentuk upaya pelestarian terhadap pusaka budaya tak ragawi menurut Pendidikan Pusaka Indonesia (2010:36) yang mengacu pada UNESCO (2003):

a. Preservasi, kegiatan untuk mempertahankan keutuhan pusaka budaya tak ragawi yang dapat dilakukan melalui pengembangan pusat data, dokumentasi dan informasi terpadu mengenai kesenian.

b. Trasmisi budaya, kegiatan menyebarkan pesan atau budaya dari satu generasi ke generasi yang lain sebagai suatu bentuk pewarisan budaya untuk meneruskan kebudayaan yang ada.

c. Revitalisasi budaya, kegiatan untuk menghidupkan kembali suatu kebudayaan sehingga menjadi penting bagi kehidupan sosial budaya masyarakat.

\section{Zonasi Pelestarian Kawasan}

Zonasi merupakan bentuk alokasi wilayah secara geografis untuk kepentingan tertentu dan distribusi ruang sesuai dengan intensitas kepentingan manusia untuk kepentingan konservasi (Nuryanti, 2008). Menurut UU No. 11 Tahun 2010 pembagian ruang suatu Situs atau Kawasan Cagar Budaya dilakukan berdasarkan tingkat kepentingan dan rencana pemanfaatannya, yaitu:

1. Zona Inti, area perlindungan utama untuk menjaga bagian terpenting Cagar Budaya.

2. Zona Penyangga, area yang melindungi zona inti.

3. Zona pengembangan, area yang diperuntukkan bagi pengembangan potensi Cagar Budaya bagi kepentingan rekreasi, daerah konservasi lingkungan alam, lanskap budaya, kehidupan budaya tradisional, keagamaan, dan kepariwisataan.

4. Zona Penunjang adalah area yang diperuntukkan bagi sarana dan prasarana penunjang serta untuk kegiatan komersial dan rekreasi umum.

\section{Kriteria Wisata Religi}

Istilah wisata religi (religious tourism) telah ada sejak jaman kuno di Mesir, Yunani, dan India yang merupakan kegiatan wisata yang dilakukan semata-mata untuk tujuan mengunjungi tujuan keagamaan yang disebut ziarah (Chadha, 2016:1709). Wisata religi merupakan suatu perjalanan untuk beberapa saat dan tidak lebih dari satu tahun untuk mengunjungi tempat suci dan pusat keagamaan (Yakunin, 2016: 2597). Pada dasarnya dalam wisata religi terdapat suatu daya tarik wisata bagi para pengunjung yang berwujud bangunan suci atau tempat berziarah. Tujuan dari wisata religi dapat diklasifikasikan sebagai berikut:

a. Perayaan ritual keagamaan

b. Peningkatan kualitas diri dan penegasan keadaan spiritual 
c. Meningkatkan status pribadi dalam komunitas agama

d. Penyembahan tempat suci

e. menerima kesembuhan secara spiritual dan fisik

f. Pengetahuan baru tentang spiritual

g. Mendapatkan kesenangan estetika arsitektur, lukisan, ikon-lukisan,

Menurut Purwadio (2011:2) terdapat faktor-faktor yang mempengaruhi pengembangan kawasan wisata religi antara lain pemasaran wisata, infrastruktur, sarana wisata, sumber daya manusia, serta karakter dan budaya masyarakat.

\section{METODE}

Penelitian ini menggunakan pendekatan kualitatif dengan instrumen penelitian berupa wawancara dan observasi. Penelitian kualitatif adalah penelitian untuk memahami fenomena yang dialami oleh subjek penelitian, seperti persepsi, perilaku, motivasi, tindakan, dan lain-lain, dengan cara deskripsi atau dalam bentuk kata-kata (Moleong, 2007). Wawancara dalam penelitian ini dilakukan dengan teknik snowballing sampling. Menurut Effendi (2012: 173) snowballing sampling merupakan metode penentuan sampel yang pada awalnya sangat kecil semakin lama semakin besar jumlahnya. Wawancara dilakukan dengan sampel sebanyak 9 responden yang terdiri dari pihak Kelurahan Kauman, pihak Kelurahan Bangunharjo, pengelola Kauman Kampung Qur'an, serta masyarakat Kauman. Observasi lapangan dalam penelitian ini digunakan untuk mengidentifikasi elemen dalam kriteria kawasan wisata religi, kriteria pelestarian kawasan Kauman Semarang, maupun elemen perancangan kawasan pada arahan pelestarian. Adapun data yang dikumpulkan terkait kriteria wisata religi diantaranya sarana dan prasarana wisata, sumberdaya manusia, karakter dan budaya masyarakat, serta pemasaran wisata.

\section{TEMUAN DAN HASIL}

\section{Analisis Kriteria Pelestarian Kawasan Kauman}

Kriteria Kelayakan Pusaka Budaya Ragawi

Tabel 1. Penilaian Kelayakan Pusaka Budaya Tak Ragawi

\begin{tabular}{|c|c|c|}
\hline & Masjid Agung Semarang & Rumah Kuno \\
\hline Usia & $\begin{array}{l} \pm 400 \text { tahun (dibangun pertama kali pada } \\
\text { pertengahan abad ke- } 16 \text { ) }\end{array}$ & \pm 200 tahun (sudah ada sejak tahun 1800an) \\
\hline Kesejarahan & $\begin{array}{l}\text { Masjid peninggalan Ki Ageng Pandan } \\
\text { Arang, cikal bakal berdirinya Kota } \\
\text { Semarang }\end{array}$ & $\begin{array}{l}\text { Rumah peninggalan pada masa awal } \\
\text { terbentuknya Kota Semarang } \\
\text { dipengaruhi budaya Jawa dan Arab. }\end{array}$ \\
\hline Kelangkaan & $\begin{array}{l}\text { Memiliki kesamaan gaya arsitektur dengan } \\
\text { Masjid Agung Demak karena pengaruh wali } \\
\text { songo }\end{array}$ & $\begin{array}{l}\text { Terdapat bangunan dengan ornamen } \\
\text { bangunan yang sama di kawasan Kauman. }\end{array}$ \\
\hline $\begin{array}{l}\text { Kualitas } \\
\text { Pengaruh }\end{array}$ & $\begin{array}{l}\text { Sebagai landmark kawasan dan bermakna } \\
\text { kultural Jawa dan Arab. }\end{array}$ & $\begin{array}{l}\text { Memiliki makna kultural tersermin dari } \\
\text { bentuk dan ornamen bangunan. }\end{array}$ \\
\hline Superlativitas & Merupakan masjid tertua di Kota Semarang & Usia bangunan sudah lebih dari 50 tahun. \\
\hline Estetika & $\begin{array}{l}\text { Arsitektur bangunan bergaya Jawa dan } \\
\text { Arab }\end{array}$ & $\begin{array}{l}\text { Bentuk pintu besar dan lebar sekaligus } \\
\text { sebagai jendela rumah, bentuk atap } \\
\text { mengerucut, lantai bermotif. }\end{array}$ \\
\hline Kejamakan & $\begin{array}{l}\text { Mewakili gaya bangunan perpaduan Jawa } \\
\text { dan Arab }\end{array}$ & $\begin{array}{l}\text { Mewakili gaya bangunan perpaduan Jawa } \\
\text { dan Arab }\end{array}$ \\
\hline Nilai Sosial & Sebagai tempat ibadah umat Islam & $\begin{array}{l}\text { Tidak terdapat nilai sosial, hanya sebagai } \\
\text { tempat tinggal warga. }\end{array}$ \\
\hline $\begin{array}{l}\text { Nilai } \\
\text { Komersial }\end{array}$ & Berpotensi sebagai daya tarik wisata. & Berpotensi sebagai daya tarik wisata. \\
\hline
\end{tabular}




\begin{tabular}{lllll}
\hline & \multicolumn{3}{c}{ Masjid Agung Semarang } & \multicolumn{2}{c}{ Rumah Kuno } \\
\hline Nilai Ilmiah & $\begin{array}{l}\text { Sebagai obek ilmiah penelitian } \\
\text { berkaitan dengan sejarah kawasan. }\end{array}$ & yang & $\begin{array}{l}\text { Sebagai objek ilmiah penelitian terkait } \\
\text { arsitektur bangunan. }\end{array}$ & . \\
\hline
\end{tabular}

Sumber: Analisis Penyusun, 2018

Berdasarkan analisis penilaian kriteria kelayakan pelestarian yang telah dilakukan terhadap pusaka budaya ragawi dapat disimpulkan bahwa kawasan Kauman Semarang layak untuk dilestarikan dengan keberadaan benda peninggalan bersejarah berupa Masjid Agung Semarang dan bangunan-bangunan rumah kuno. Penilaian yang dilakukan terhadap Masjid Agung Semarang dan bangunan-bangunan rumah kuno menunjukkan bahwa di kawasan Kauman terdapat bangunan bersejarah yang memiliki nilai kesejarahan, estetika, kelangkaan, kualitas pengaruh, superlativitas, kejamakan, nilai sosial, nilai komersial, dan nilai ilmiah yang cukup tinggi.

\section{Kriteria Penilaian Kelayakan Pusaka Budaya Tak Ragawi}

Tabel 2. Penilaian Kelayakan Pusaka Budaya Tak Ragawi

\begin{tabular}{|c|c|c|c|c|c|}
\hline $\begin{array}{l}\text { Nama } \\
\text { Objek }\end{array}$ & Nilai Pengetahuan & Sumberdaya & $\begin{array}{c}\text { Warisan atau } \\
\text { Keturunan }\end{array}$ & Keistimewaan & $\begin{array}{l}\text { Nilai Sosial } \\
\text { Budaya }\end{array}$ \\
\hline $\begin{array}{c}\text { Tradisi } \\
\text { Dugderan }\end{array}$ & $\begin{array}{l}\text { Tradisi untuk } \\
\text { menyambut } \\
\text { datangnya bulan } \\
\text { suci Ramadhan } \\
\text { dengan bentuk } \\
\text { kegiatan berupa } \\
\text { pawai karnaval. }\end{array}$ & $\begin{array}{l}\text { Menggunakan } \\
\text { bunyi bedug dan } \\
\text { meriam serta } \\
\text { maskot dugderan } \\
\text { yaitu Warak } \\
\text { Ngendog }\end{array}$ & $\begin{array}{l}\text { Pertama kali } \\
\text { diadakan } \\
\text { tahun 1881 } \\
\text { yang digagas } \\
\text { oleh Bupati } \\
\text { Semarang } \\
\text { Raden Mas } \\
\text { Tumenggung } \\
\text { Purboningrat. }\end{array}$ & 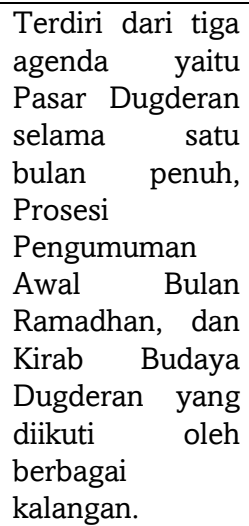 & $\begin{array}{l}\text { Menjadi sarana } \\
\text { berbaurnya } \\
\text { seluruh } \\
\text { masyarakat } \\
\text { dari berbagai } \\
\text { etnis, baik } \\
\text { pribumi (Jawa), } \\
\text { Arab, dan Cina. }\end{array}$ \\
\hline $\begin{array}{c}\text { Tradisi } \\
\text { Pengajian }\end{array}$ & $\begin{array}{lr}\text { Tradisi yang } & \text { telah } \\
\text { melekat } & \text { pada } \\
\text { masyarakat } & \\
\text { Kauman } & \text { sejak } \\
\text { dulu } & \text { dengan } \\
\text { kegiatan berupa } \\
\text { kajian tematik, } \\
\text { tassawuf, kajian } \\
\text { hadist serta kajian } \\
\text { Al-Qur'an }\end{array}$ & $\begin{array}{lr}\text { Dilaksanakan di } \\
\text { TPQ, mushola, } \\
\text { majelis } & \text { ta'lim } \\
\text { maupun } & \text { masjid } \\
\text { mulai } & \text { dari } \\
\text { kalangan } & \text { anak- } \\
\text { anak } & \text { sampai } \\
\text { dewasa. } & \end{array}$ & $\begin{array}{l}\text { Sudah ada } \\
\text { sejak jaman } \\
\text { dahulu. }\end{array}$ & $\begin{array}{l}\text { Memperkuat } \\
\text { suasana religius } \\
\text { pada kawasan } \\
\text { Kauman. }\end{array}$ & $\begin{array}{l}\text { Mempererat } \\
\text { hubungan } \\
\text { antar warga } \\
\text { masyarakat di } \\
\text { Kauman } \\
\text { melalui } \\
\text { kegiatan } \\
\text { pengajian }\end{array}$ \\
\hline $\begin{array}{l}\text { Tradisi } \\
\text { Semaan Al } \\
\text { Qur'an }\end{array}$ & $\begin{array}{l}\text { Merupakan tradisi } \\
\text { mendengarkan } \\
\text { penjelasan atau } \\
\text { tafsir dari setiap } \\
\text { ayat Al Qur'an } \\
\text { yang dilaksanakan } \\
\text { setiap bulan } \\
\text { Ramadhan. }\end{array}$ & $\begin{array}{lr}\text { Dilaksanakan } & \text { di } \\
\text { Masjid } & \text { Agung } \\
\text { Semarang } & \text { yang } \\
\text { dipimpin } & \text { oleh } \\
\text { ulama } & \text { dan } \\
\text { penghafal } & \\
\text { Alquran } & \mathrm{KH} \\
\text { Ahmad } & \text { Naqib } \\
\text { Nur } & \text { Alhafidz } \\
\text { dan diikuti } & \text { oleh } \\
\text { jamaah } & \text { dari } \\
\text { dalam maupun } \\
\text { luar } & \text { kawasa } \\
\text { Kauman. } & \end{array}$ & $\begin{array}{l}\text { Awalnya } \\
\text { dipelopori } \\
\text { oleh } \mathrm{KH} \\
\text { Abuya pada } \\
\text { tahun } 1970 .\end{array}$ & $\begin{array}{lr}\text { Jamaah } & \text { yang } \\
\text { hadir bukan } & \text { banya } \\
\text { hari } \\
\text { Semarang, akan } \\
\text { tetapi ruga } \\
\text { berasal dari } \\
\text { luar Semarang } \\
\text { seperti Demak, } \\
\text { Purwodadi, } \\
\text { Kendal bahkan } \\
\text { Kalimantan. }\end{array}$ & $\begin{array}{l}\text { Menjadi ruang } \\
\text { bagi } \\
\text { berkumpulnya } \\
\text { masyarakat } \\
\text { khususnya } \\
\text { umat Islam } \\
\text { yang tidak } \\
\text { hanya berasa } \\
\text { ldari wilayah } \\
\text { Kauman. }\end{array}$ \\
\hline
\end{tabular}

Sumber: Analisis Penyusun, 2018 
Berdasarkan tabel tersebut maka dapat dianalisis kelayakan pelestarian kawasan Kauman berdasarkan pada kriteria penilaian kelayakan pusaka budaya tak ragawi. Kelayakan Kauman sebagai kawasan pelestarian tidak hanya dinilai berdasarkan keberadaan pusaka budaya ragawi, akan tetapi penilaian juga dilakukan terdahap pusaka budaya tak ragawi yang ada di kawasan dalam hal ini tradisi dugderan, tradisi pengajian, dan tradisi semaan Al Qur'an. Ketiga tradisi tersebut mengandung unsur nilai pengetahuan, sumberdaya, warisan atau keturunan, keistimewaan, dan memiliki nilai sosial budaya yang layak untuk dipertahankan dan dijaga kelestariannya.

\section{Analisis Kriteria Wisata Religi Kawasan Kauman}

1. Sarana Wisata

Sarana wisata di kawasan Kauman cukup layak dinilai berdasarkan ketersediaan dan kondisi dari masing-masing sarana. Pada kawasan Kauman terdapat sarana wisata berupa atraksi wisata, penginapan, kuliner, peribadatan, toko souvenir, dan transportasi dengan kondisi yang cukup baik. Akan tetapi belum terdapat sarana kesehatan khusus untuk kegiatan wisata sehingga diperlukan adanya penambahan sarana tersebut serta pengembangan terhadap sarana yang telah tersedia.

2. Prasarana Wisata

Berdasarkan ketersediaan prasarana wisata, kawasan Kauman memiliki prasarana wisata yang cukup memadai dengan kondisi yang baik untuk mencukupi kebutuhan kegiatan wisata religi. Prasara wisata yang dimaksud antara lain berupa jaringan jalan, jaringan air bersih, jaringan listrik, dan perbankan.

3. Sumberdaya Manusia

Keberadaan sumberdaya manusia di kawasan Kauman tercermin dari adanya pondokpondok pesantren sebagai sarana untuk meningkatkan kualitas sumberdaya manusia melalui kegiatan edukasi religi yang ada di dalamnya. Selain sumberdaya manusia dari masyarakat Kauman memiliki potensi mendukung kegiatan wisata dalam bidang kuliner yaitu usaha pembuatan jajanan tradisional kawasan.

4. Karakter dan Budaya Masyarakat

Masyarakat kauman memiliki karakter dan budaya dengan nilai agamis yang tercermin dari adanya tradisi pengajian, tradisi semaan Al Qur'an serta budaya mengaji di TPQ dan mushola yang telah diterapkan sejak usia dini.

5. Pemasaran wisata

Pemasaran wisata di Kauman dilakukan oleh pengelola Kauman Kampung Qur'an melalui komunitas remaja masjid dengan cara publikasi program-program dari Kauman Kampung Qur'an yang dilakukan secara online melaui facebook dan website resmi milik Kauman Kampung Qur'an.

\section{Analisis Zonasi Pelestarian Kawasan}

Tabel 3. Analisis Zonasi Pelestarian Kawasan Kauman

\begin{tabular}{lll}
\hline Data & \multicolumn{1}{c}{ Analisis } & Respon \\
\hline & Pemanfaatan pada zona inti & Zona Inti \\
pelestarian Kauman adalah & \\
dengan menjadikan zona inti & \\
sebagai ruang bagi kegiatan & \\
untuk mempertahankan & keaslian bangunan dengan \\
tidak mengubah ornamen dan & \\
bentuk bangunan yang telah & \\
& ada. Berdasarkan RPP Tentang &
\end{tabular}




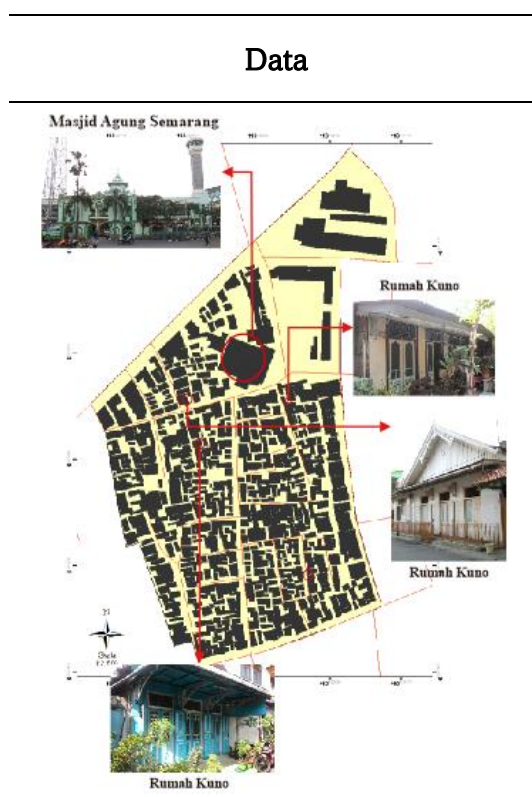

- Pusaka budaya ragawi berupa bangunan Masjid Agung Semarang dan bangunan-bangunan rumah kuno.

- Pusaka budaya tak ragawi: tradisi dugderan, tradisi pengajian, dan tradisi semaan $\mathrm{Al}$ Qur'an.
Analisis

Cagar Budaya, pemanfaatan zona inti dilakukan ketentuan sebagai berikut:

a. Mutlak untuk mempertahankan keaslian Cagar Budaya.

b. Tidak boleh merusak atau mencemari Cagar Budaya maupun nilainya.

c. Tidak boleh mengubah fungsi, kecuali tetap mempertahankan prinsip pelestarian Cagar Budaya.

d. Tidak boleh untuk kepentingan komersial, kecuali memenuhi kepatutan.

e. Tidak boleh didirikan bangunan baru atau fasilitas lain kecuali taman, fasilitas pelindung, dan fasilitas pengamanan.

f. Tidak menjadi ruang kegiatan yang bertentangan dengan sifat kesakralan.
Respon

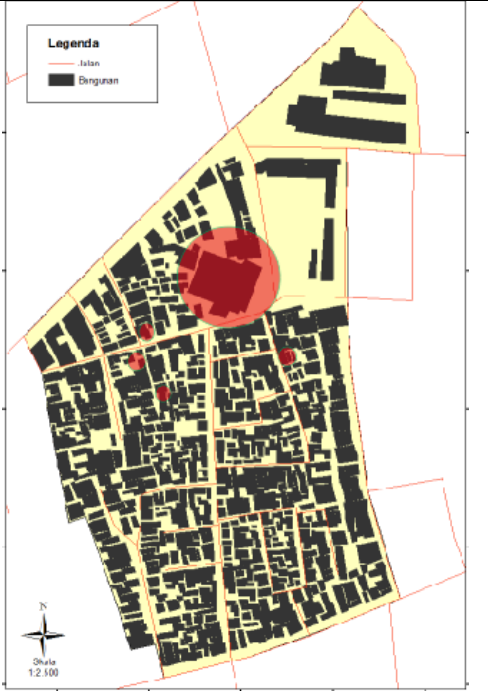

- Masjid Agung Semarang tetap diperuntukkan sebagai tempat beribadah dan sarana bagi tradisi pengajian dan semaan Al Qur'an.

- Bangunan rumah kuno tetap diperuntukkan sebagai hunian dengan perawatan agar tidak terjadi kerusakan bentuk dan nilai sejarah yang dimilikinya.

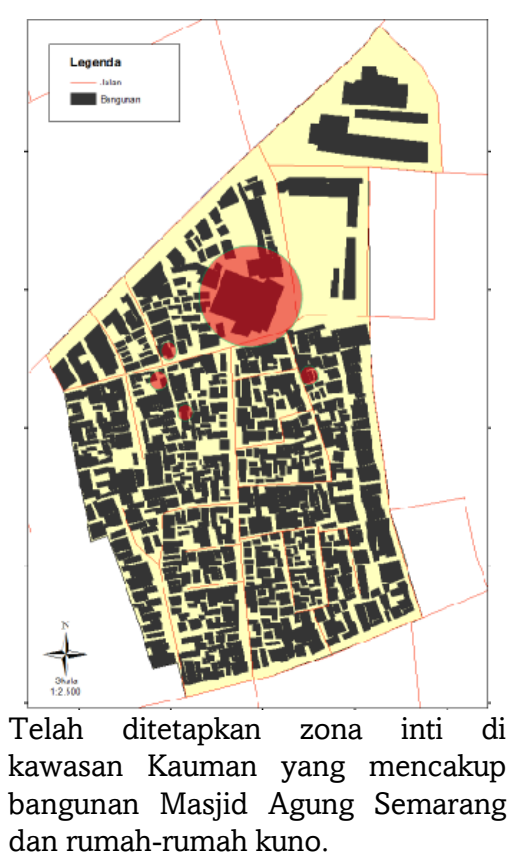

Zona Penyangga adalah area yang melindungi zona inti. Berdasarkan RPP Tentang Cagar Budaya, pemanfaatan zona penyangga dilakukan ketentuan sebagai berikut:

a.Tidak boleh untuk kepentingan komersial, kecuali memenuhi kepatutan.

b.Tidak boleh didirikan bangunan baru atau fasilitas lain kecuali taman, fasilitas pendukung, dan fasilitas pengamanan.

c.Dapat digunakan untuk ruang kegiatan yang tidak bertentangan dengan kelestarian.

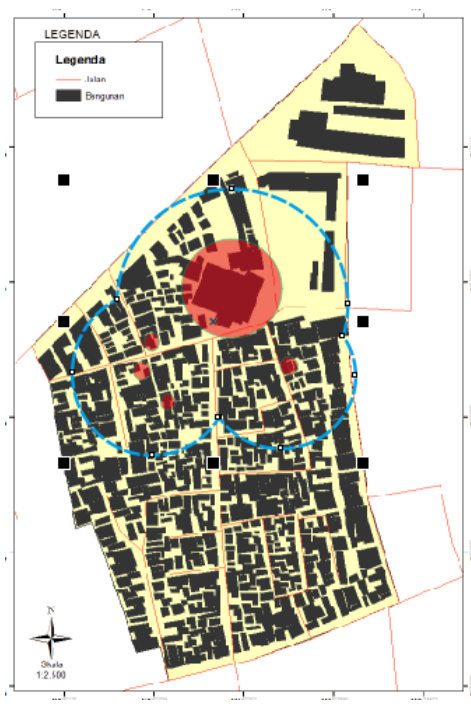

Zona penyangga pada penelitian ini adalah area di luar zona inti (Masjid Agung Semarang dan bangunan rumah kuno) dengan radius 100 meter yang berfungsi untuk melindungi kelestarian pada zona inti. 


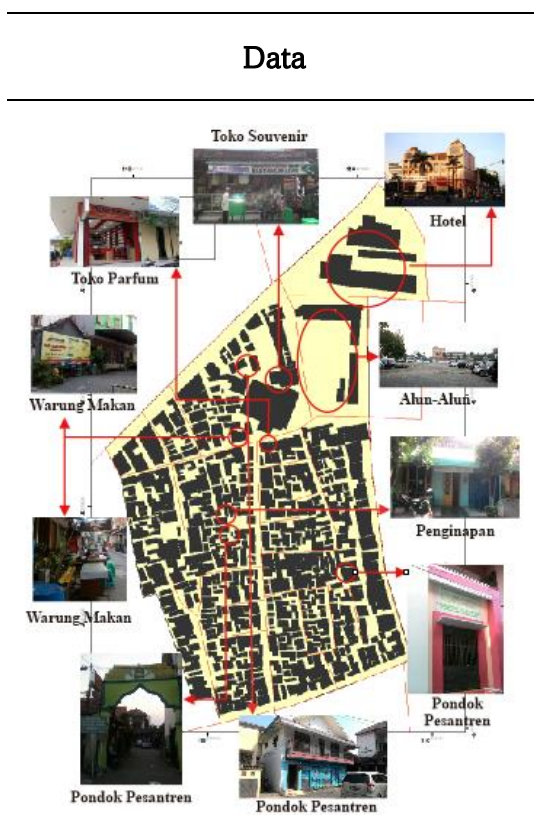

Terdapat elemen yang perlu untuk dikembangkan untuk mendukung Kauman sebagai kawasan wisata religi mencakup aspek yang telah tersedia seperti sarana akomodasi, kuliner, toko souvenir, alun-alun, pondok pesantren, serta aspek yang belum ada seperti fasilitas kesehatan bagi kegiatan wisata.
Zona pengembangan meliputi area yang akan dikembangkan untuk mendukung Kauman sebagai kawasan wisata edukasi religi. Pemanfataan ruang pada zona pengembangan ini diatur dengan ketentuan sebagai berikut:
a. Mengembangkan nilai manfaat dari Cagar Budaya.

b. Dapat dipergunakan untuk tempat fasilitas umum.

c. Dapat dipergunakan untuk kawasan permukiman dan fasilitas pendukung.

d. Dapat untuk kepentingan komersial dengan mempertahankan nilai lingkungan budaya.
Respon

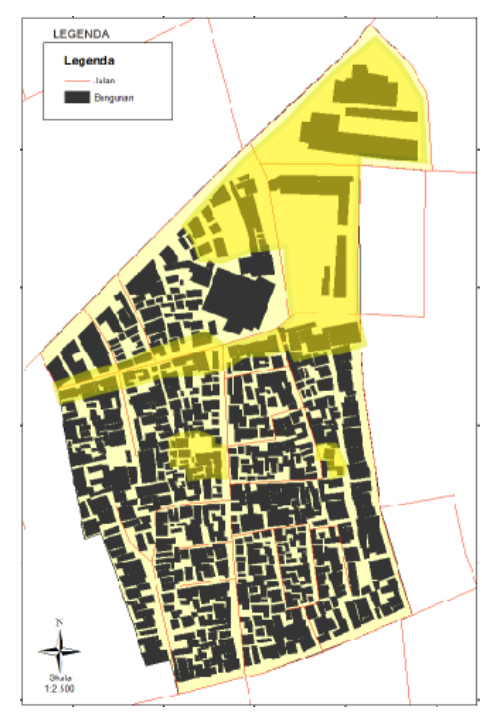

Adapun aspek yang dikembangkan pada zona pengembangan antara lain berupa edukasi religi, wisata kuliner serta sarana pendukung wisata berupa akomodasi toko souvenir, rumah makan, fasilitas kesehatan, dan alun-alun.

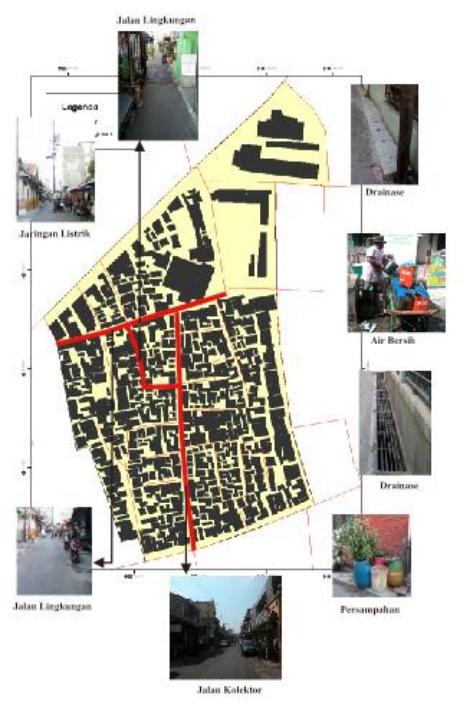

Zona Penunjang adalah area yang diperuntukkan bagi prasarana penunjang serta untuk kegiatan komersial dan rekreasi umum. Luas zona penunjang disesuaikan dengan kondisi dan kebutuhan setempat. Berikut ketentuan dalam pemanfaatan ruang pada zona penunjang:

a. Diperuntukkan bagi penempatan sarana dan prasarana penunjang.

b. Untuk kegiatan komersial dan rekreasi umum.

c. Luas zona penunjang disesuaikan dengan kondisi dan kebutuhan setempat.

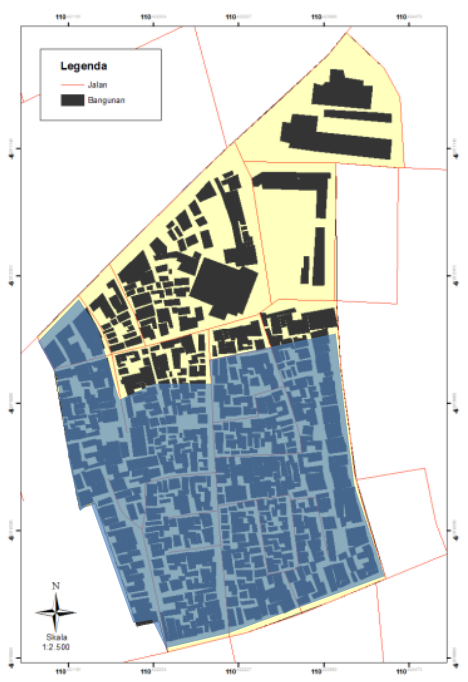

Pada penelitian ini zona penunjang adalah kawasan Kauman beserta dengan prasarana yang dimilikinya seperti jaringan jalan, jaringan air bersih, persampahan, drainase, maupun jaringan listrik. Zona ini merupakan ruang bagi kegiatan komersial yang bersifat umum seperti perdagangan dan jasa eksisting. 


\section{Analisis Pelestarian Kauman Semarang Sebagai Kawasan Wisata Religi}

\section{Analisis Tata Guna Lahan}

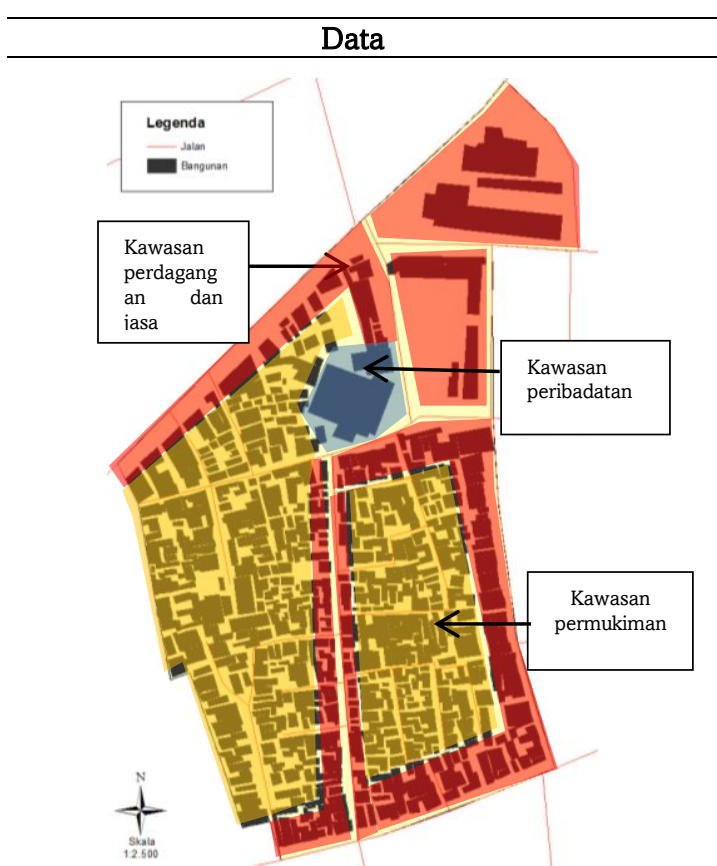

Penggunaan lahan di kawasan Kauman adalah sebagai kawasan permukiman serta perdagangan dan jasa.

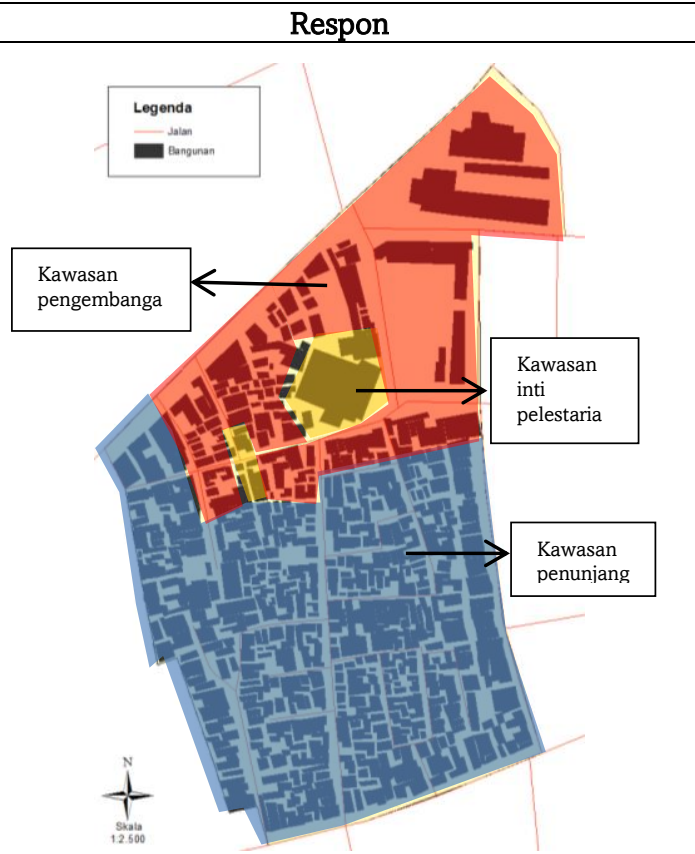

Dalam pengembangannya, kawasan Kauman terbagi menjadi kawasan inti pelestarian, kawasan pengembangan wisata, dan kawasan penunjang wisata.

\section{Analisis Jalur Pejalan Kaki}

Data
$\begin{aligned} & \text { Pada kawasan Kauman belum terdapat jalur pejalan } \\ & \text { kaki disebabkan padatnya bangunan serta } \\ & \text { penggunaan ruang pada bagian depan bangunan } \\ & \text { sebagai parkir bagi kendaraan sehingga tidak tersisa } \\ & \text { lagi ruang antara jalan dengan bangunan yang } \\ & \text { seharusnya digunakan sebagai trotoar dan ruang } \\ & \text { bagi pejalan kaki. }\end{aligned}$


Analisis Sirkulasi dan Parkir

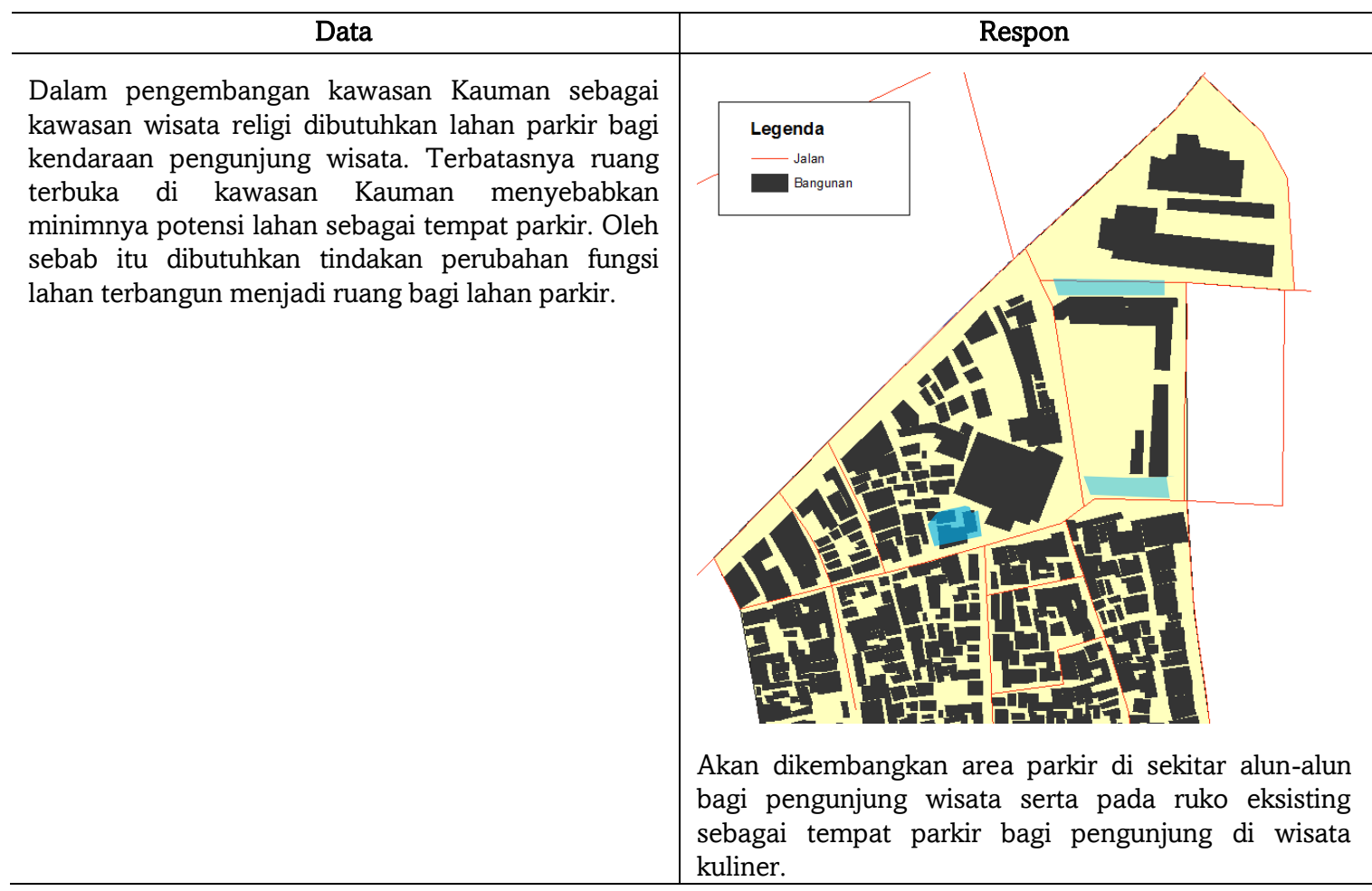

\section{Analisis Ruang Tebuka}

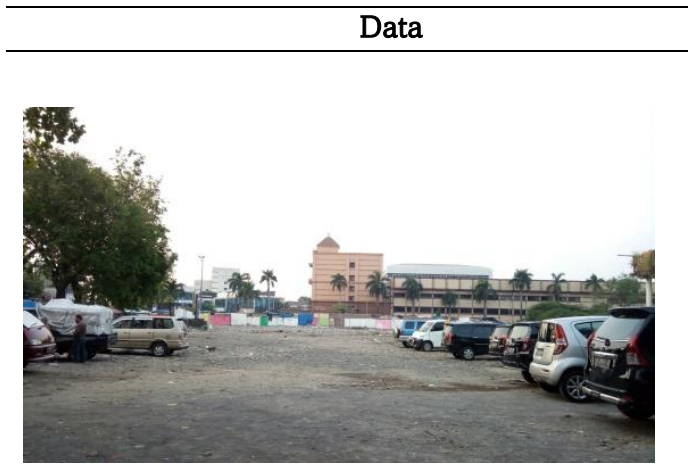

Peruntukan ruang di kawasan Kauman yang dominan sebagai ruang terbangun menyebabkan Kauman kekurangan ruang terbuka. Pengembalian fungsi alunalun yang awalnya merupakan tempat parkir kendaraan dan aktivitas Pasar Ya'ik berpotensi sebagai ruang terbuka yang berfungsi sebagai tempat bersosialisasi masyarakat dan pendukung kegiatan wisata di kawasan Kauman.

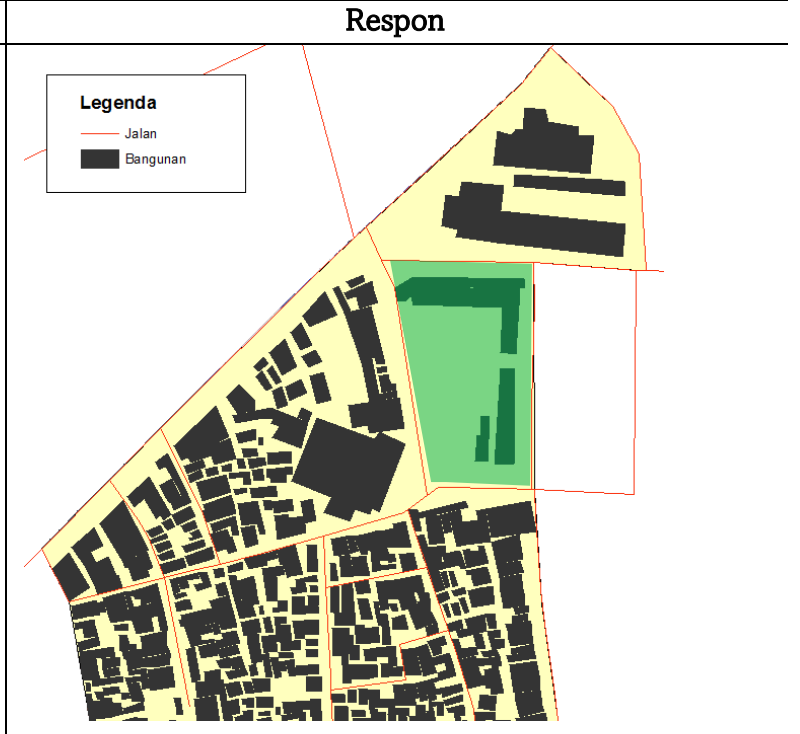

Alun-alun yang terletak di depan Masjid Agung Semarang merupakan sarana yang potensial dalam mendukung kegiatan wisata di kawasan Kauman. Adanya alun-alun tersebut dapat dikembangkan sebagai ruang terbuka hijau sekaligus ruang bagi kegiatan wisata religi. 


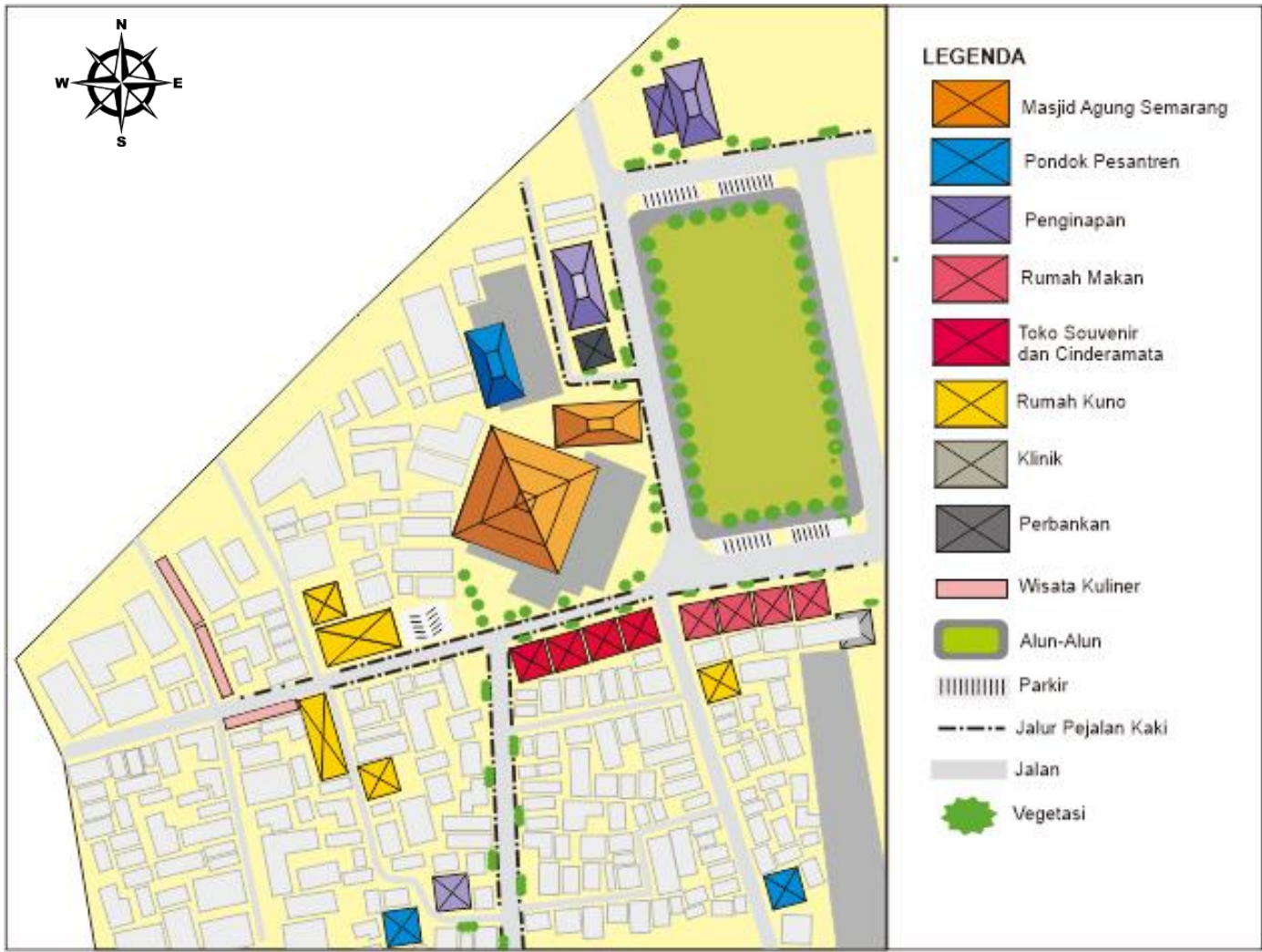

Sumber: Analisis Penyusun, 2018

Gambar 1. Peta Pengembangan Wisata Religi di Kauman

Berikut merupakan hasil dari analisis arahan pengembangan Kauman sebagai kawasan wisata religi:

1. Pusaka Budaya Ragawi

Mengacu pada Yoeti (1983) potensi wisata Masjid Agung Semarang dan bangunan rumah kuno something to see karena ketiga peninggalan bersejarah tersebut dapat menjadi sesuatu yang dapat dinikmati oleh wisatawan.

Masjid Agung Semarang, merupakan masjid tertua di Kota Semarang dengan arsitektur perpaduan budaya Jawa dan Arab serta nilai sejarah yang dimilikinya berpotensi sebagai daya tarik bagi wisatawan untuk berkunjung ke kawasan Kauman. Selain itu terkait fungsi bangunan sebagai ruang bagi kegiatan keagamaan seperti pengajian dan semaan $\mathrm{Al}$ Qur'an, maka maka hal tersebut yang kemudian menjadikan Masjid Agung Semarang sebagai sebuah potensi wisata religi bagi kawasan Kauman.

Bangunan Rumah Kuno, merupakan bangunan dengan ornamen dan bentuk arsitektur perpaduan Jawa dan Arab yang dapat menjadi sebuah daya tarik bagi wisatawan. Hal tersebut karena selama ini bangunan rumah kuno tersebut telah menjadi objek penelitian di bidang pendidikan dan ilmu pengetahuan serta sering dijadikan sebagai objek fotografi oleh masyarakat.

2. Pusaka Budaya Tak Ragawi

Mengacu pada Yoeti (1983) tradisi dugderan termasuk dalam kriteria something to see karena ketiga peninggalan bersejarah tersebut dapat menjadi sesuatu yang dapat dinikmati oleh wisatawan. Sedangkan tradisi semaan Al Qur'an masuk dalam kriteria 
something to do karena tradisi tersebut berbentuk kegiatan tafsir dan kajian $\mathrm{Al}$ Qur'an yang dapat dilakukan oleh para wisatawan.

Tradisi Dugderan, merupakan tradisi turun temurun untuk menyambut bulan suci Ramadhan. Tradisi dugderan ini merupakan suatu rangkaian acara yang terdiri dari tiga agenda yaitu Pasar Dugderan selama satu bulan penuh, Prosesi Pengumuman Awal Bulan Ramadhan, dan Kirab Budaya Dugderan yang diikuti oleh berbagai kalangan. Hal tersebut merupakan daya tarik bagi pengunjung di luar kawasan Kauman terutama saat acara pasar dugderan dan kirab budaya dugderan dilaksanakan,

Tradisi Semaan Al Qur'an, merupakan tradisi yang telah ada sejak dulu dengan keiatan berupa mendengarkan penjelasan atau tafsir dari setiap ayat Al Qur'an yang dilaksanakan setiap bulan Ramadhan. Tradisi ini merupakan salah satu potensi daya tarik wisata bagi Kauman khususnya sebagai wisata edukasi religi dibuktikan oleh antusiasme yang tinggi dari para jamaah yang datang dari luar Kota Semarang, seperti Demak, Purwodasi, Kendal, bahkan Kalimantan.

3. Edukasi Religi

Adanya pondok-pondok pesantren di Kauman dapat menjadi pendukung dalam pengembangan Kauman menjadi kawasan wisata edukasi religi. Pondok-pondok pesantren tersebut sebagai tempat menimba ilmu menghapal Al Qur'an memiliki nilai lebih yaitu memiliki sanad yang jelas sehingga para hafidz yang lulus dari pondok pesantren tersebut memiliki jaminan keilmuan yang jelas sehingga dapat menarik minat calon santri yang ingin mondok di Kauman.

Mengacu pada Yoeti (1983), kegiatan hapalan Al Qur'an yang ada di pondok-pondok pesantren di Kauman dapat menjadi aspek something to see. Hal tersebut karena kegiatan hapalan Al Qur'an dapat menjadi sesuatu yang ditawarkan dari segi edukasi religi kepada para wisatawan yang berkunjung.

4. Wisata Kuliner

Pemerintah akan mengembangkan wisata kuliner di kawasan Kauman tepatnya di RW8, Kelurahan Bangunharjo. Rencana tersebut dilatarbelakangi oleh banyaknya warga Kauman yang berjualan jajanan tradisional seperti lumpia, klepon, nogosari, ganjel rel, dan ganjrit. Para pedagang tersebut masih belum memiliki tempat berjualan yang tetap sehingga Pemerintah merencanakan lapak untuk para pedagang yang dikemas dalam bentuk wisata kuliner. Wisata kuliner akan diakadan seminggu tiga kali, yaitu setiap hari jumat, sabtu, dan minggu.

Adanya wisata kuliner di kawasan Kauman tersebut dapat mendukung pengembangan wisata religi. Mengacu pada Yoeti (1983), dalam hal ini kegiatan wisata kuliner yang direncanakan oleh Pemerintah merupakan salah satu bentuk kegiatan yang dapat mendukung kegiatan wisata di Kauman.

5. Sarana Wisata

- Penginapan

Kegiatan-kegiatan keagamaan yang ada di Kauman membutuhkan adanya akomodasi bagi wisatawan yang berkunjung. Tradisi semaan Al Qur'an yang dilaksanakan setiap bulan Ramadhan serta kegiatan pengajian yang sering digelar di area Masjid Agung Semarang telah mampu menarik jamaah dari luar Kota Semarang bahkan luar Jawa. Oleh sebab itu untuk mendukung kegiatan tersebut diperlukan adanya penginapan sebagai tempat beristirahat bagi para jamaah. Pada kawasan Kauman telah tersedia akomodasi berupa hotel dan penginapan yang masih memerlukan pengembangan dalam penyediaannya.

- Toko souvenir dan cinderamata 
Pada kawasan Kauman telah berdiri usaha-usaha yang berpotensi mendukung kegiatan wisata edukasi religi diantaranya toko souvenir yang menjual peralatan sholat dan kegiatan keagamaan, toko-toko parfum, serta percetakan Al Qur'an. Hal tersebut yang kemudian dapat dijadikan sebagai potensi oleh-oleh atau cinderamata dari kawasan Kauman.

- Rumah makan

Pada kawasan Kauman terdapat rumah makan dengan kondisi yang kurang memadai baik dari segi kualitas maupun kuantitas. Jumlah rumah makan yang masih jarang dengan kondisi yang masih belum sesuai sebagai penkung kegiatan wisata sehingga diperlukan adanya pengembangan terhadap penyediaannya.

- Fasilitas kesehatan

Pada kawasan Kauman belum tersedia fasilitas kesehatan khusus bagi kegiatan wisata. Fasilitas kesehatan yang dimaksud dapat berupa klinik yang dapat memberikan pertolongan pertama yang diperuntukkan terutama bagi pengunjung wisata. Oleh karena itu perlu adanya pengembangan terhadap fasilitas kesehatan dengan lokasi yang mudah dijangkau dan terhubung dengan sarana dan prasarana wisata yang lain.

- Alun-alun

Alun-alun yang terletak di depan Masjid Agung Semarang merupakan sarana yang potensial dalam mendukung kegiatan wisata di kawasan Kauman. Adanya alunalun tersebut dapat dikembangkan sebagai ruang terbuka hijau sekaligus ruang bagi kegiatan wisata edukasi religi. Hal tersebut karena alun-alun dapat menjadi tempat yang mendukung kegiatan pengajian yang sering diadakan oleh pengelola Kauman Kampung Qur'an. Pengajian dan tausiah akbar yang sering digelar di area Masjid Agung Semarang tersebut membutuhkan sarana pendukung dengan kapasitas ruang yang lebih besar sehingga keberadaan alun-alun sangat potensial sebagai pendukung Kauman sebagai kawasan wisata religi.

\section{KESIMPULAN}

Upaya pelestarian dilakukan terhadap pusaka budaya ragawi yaitu Masjid Agung Semarang dan bangunan-bangunan rumah kuno serta terhadap pusaka budaya tak ragawi yang terdiri dari tradisi pengajian, tradisi dugderan, dan tradisi semaan Al Qur'an. Sedangkan untuk mendukung hal tersebut diperlukan arahan pengembangan wisata religi yang dilakukan terhadap sarana dan prasarana pendukung wisata serta potensi wisata yang ada di Kauman berupa wisata kuliner dan edukasi religi dari pondok-pondok pesantren dan pengajian yang ada di kawasan Kauman.

Hasil dari penelitian ini dapat digunakan sebagai bahan pertimbangan dalam menentukan arahan pelestarian kawasan Kauman. Pelestarian dapat dilakukan dengan mengarahkan Kauman untuk dikembangkan sebagai kawasan wisata sesuai dengan karateristik dan potensi religius yang dimiliki. Pemkot dapat melakukan penetapan bangunan rumah kuno sebagai Benda Cagar Budaya serta melakukan pendekatan atau sosialisasi kepada masyarakat mengenai pentingnya pelestarian kawasan yang tidak hanya untuk mendapatkan tujuan pemeliharaan bangunan saja, akan tetapi secara fungsional dapat meningkatkan perekonomian masyarakat di kawasan Kauman melalui pengembangan wisata religi. Selain itu dalam proses perencanaan kawasan perlu melibatkan dan menyelaraskan persepsi dengan stakeholder terkait, seperti pihak pengelola Kauman Kampung Qur'an dan pihak kelurahan agar tidak terjadi perbedaan kebijakan dalam pengembangan kawasan. 


\section{DAFTAR PUSTAKA}

Antariksa. (2007). Beberapa Teori Dalam Pelestarian Bangunan.

Budiharjo, E. (1997). Arsitektur Sebagai Warisan Budaya. Jakarta: Djambatan.

Chadha, Ar.Harsimran \& Preeti Onkar (2016). Changing Cities in the Perspective f Religious Tourism - A case of Allahabad. Procedia - International Conference on Emerging Trends in Engineering, Science and Technology (ICETEST). 1706-1713

Effendi, S. dan T. (2012). Metode Penelitian Survei. Jakarta: LP3ES.

Hegazy, S. M. (2015). Conservation of historical buildings - The Omani-French museum as a case study. HBRC Journal, 11(2), 264-274. https://doi.org/10.1016/j.hbrcj.2014.03.010

Moleong, L. J. (2007). Metode Penelitian Kualitatif. Bandung: PT Remaja Rosdakarya.

Nurini. (2011). Kajian Pelestarian Kampung Kauman Kudus Sebagai Kawasan Bersejarah Penyebaran Agama Islam, 32(1), 9-18.

Nuryanti, Wiendu dan Nindyo Suwarno (2008). Kajian Zonasi Pengembangan Kawasan Pusaka; Studi Kasus: Situs Sangiran, Sragen. Yogyakarta: Jurnal Manusia dan Lingkungan, Vol. 15, No. 3.

P, A. I. I., Purwadio, H., Studi, P., Wilayah, P., \& Tehnik, F. (2011). Pengembangan Kawasan Wisata Religi Kompleks Makam Syaihona Moh . Kholil Bangkalan, 1-3.

Rot, Eddy, Kresimir Mikinac, and Sinisa Bogdan (2014). General Characteristics of Religious Tourism in Croatia. UTMS Journal of Economics 5 (1): 79-87.

Singh, R. P. B., \& Rana, P. S. (2017). Varanasi : Heritage Zones and its designation in UNESCO 's World Heritage Properties,

Wijanarka (2007). Semarang Tempo Dulu: Teori Desain Kawasan Bersejarah. Yogyakarta: Ombak.

Yakunin, V. N. (2016). Religious Tourism and Pilgrimae in Russia: Cultural-Historical Analysis. The Turkish Online Journal of Design, Art, and Communication, (November), 2595-2603.

Yoeti, O. A (1985). Pengantar Ilmu Pariwisata. Bandung: Angkasa.

Zahnd, M. (2008). Model Baru Perancangan Kota yang Kontekstual: Kajian Tentang Kawasan Tradisional di Kota Semarang dan Yogyakarta Suatu Potensi Perancangan Kota yang Efektif. Semarang: Kanisius 